\title{
Determining the Effective Mass Transfer Area in Three-Phase Fluidized Bed with Low Density Inert Solids
}

\begin{abstract}
SIMION DRAGAN*
Babes Bolyai University, Faculty of Chemistry and Chemical Engineering, 1 M. Kogalniceanu Str., 400084, Cluj Napoca, Romania

The absorption process is strongly influenced by the effective mass transfer area. In this study the effective mass transfer area in gas-solid-liquid three-phase fluidized bed was determined, in a fluidizing column having an internal diameter of $0.14 \mathrm{~m}$ and a height of $1.10 \mathrm{~m}$. The solid packing is made of plastic hollow spheres of $0.01 \mathrm{~m}$ diameter, with $415 \mathrm{~m}^{2} / \mathrm{m}^{3}$ geometric area and a density of $170 \mathrm{Kg} / \mathrm{m}^{3}$. The absorption of carbon dioxide from the air-carbon dioxide mixture with molar concentration of $0.05 \mathrm{M}, 0.08 \mathrm{M}$ and $0.1 \mathrm{M} \mathrm{CO}_{2}$ into sodium hydroxide aqueous solutions of $0.5 \mathrm{~N}$ and $1.0 \mathrm{~N}$ has been employed as test reaction. The experiments were conducted with liquid load changing from 6.49 to $16.24 \mathrm{~m}^{3} /\left(\mathrm{m}^{2} \mathrm{~h}\right)$ and gas velocity of 1.1 $\mathrm{m} / \mathrm{s}$ and $2.1 \mathrm{~m} / \mathrm{s}$. It was found that the effective mass transfer area increased both with the increase of the gas velocity and the increase of the liquid spray density. I thas been observed that the effective mass transfer area in gas-solid-liquid three-phase fluidized bed absorber is from three to eight times higher than the geometric area of the solid packing. A mathematical correlation has been established in order to predict the effective mass transfer area, under the specified conditions, with a deviation of less than $5 \%$.
\end{abstract}

Keywords: Effective mass transfer area, three-phase fluidized bed with low density inert solid packing, mass transfer model, chemical method, reaction regime

The environmental problems have received much more attention all over the world. In the last few years there has been a continuous development of absorption processes, both for technological purposes and for gas depollution processes due to the severity of the legislation imposed for the prevention of air and water pollution. Therefore, the reactors used were diversified according to the appearance of new types of column interiors [ 1-3]. In order to obtain maximum absorption efficiency, it is necessary to use proper equipment to maximize gas-liquid contact, such as new columns with three phase fluidized beds [4-7]. Gassolid-liquid three phase fluidized bed absorber is a mass transfer equipment in which the bed of low density packing is fluidized by the counter current flow of gas continuous phase and liquid as a dispersed phase. Low density inert solid of hallow spherical balls are used in the column being fluidized by gas. The solid packing, having no chemical effect on the process, maximizes gas-liquid contact. The intensive mixing of the solid packing in the column determines high turbulence and, enhances the mass transfer in comparison with conventional fixed beds. This contact mode between phases has many advantages for mass transfer systems in depollution processes: low pressure drop in the column, very high interfacial contact area per unit volume of the column, capability to process large volume of gases and low capital cost of the equipment. These attributes make the three phase fluidized bed absorbers technologically favourable for pollution control.

The efficiency of the mass transfer processes depends on many factors such as the effective interfacial mass transfer area, the mass transfer coefficients and the liquid holdup. Mass transfer performance can be characterized in terms of two parameters: the mass transfer coefficient $\left(\mathrm{k}_{\mathrm{f}}\right.$ or $\mathrm{k}^{0}{ }^{)}$and the gas-liquid mass transfer area, also referred to as the effective transfer area $\left(a_{0}\right)$.

One of the most important efficiency parameters for the separation columns is the effective interfacial mass transfer area $\left(a_{e}\right)$ provided by the column internals. To achieve the optimum column design, accurate knowledge of effective mass transfer area $\left(a_{\mathrm{e}}\right)$ is vital. Current research is focused especially on the effective mass transfer area measurement of three phase fluidized bed column with low density inert solid packing.

The most usual absorption system employed for determining interfacial mass transfer area with the use of the chemical method is the reactive absorption of $\mathrm{CO}$ into aqueous solutions of sodium hydroxide [8-12]. The líquid phase reaction is considered to fall in the fast reaction regime with the mechanism given by Tsai [11, 12].

The effective mass transfer area can be calculated using a reactive absorption system such as air- $\mathrm{CO}_{2}-\mathrm{NaOH}$. Because the kinetics of the system is well-known and the chemicals are easy to handle, this system with a pseudofirst reaction order has been chosen as a model reaction in this study. The absorption process can be described using the two film theory, where the liquid phase mass transfer coefficient is corrected for the chemical reaction [9].

When carbon dioxide is absorbed and reacts with aqueous sodium hydroxide solutions, the following three reactions take place [13]:

$$
\begin{aligned}
& \mathrm{CO}_{2(\mathrm{~g})} \rightarrow \mathrm{CO}_{2(())} \\
& \mathrm{CO}_{2}+\mathrm{HO}^{-} \rightarrow \mathrm{HCO}_{3}^{-} \\
& \mathrm{HCO}_{3}^{-}+\mathrm{HO}^{-} \rightarrow \mathrm{CO}_{3}^{2-}+\mathrm{H}_{2} \mathrm{O}
\end{aligned}
$$

Reaction 1 denotes the physical absorption of $\mathrm{CO}_{2}$ by water, accompanied by the heat of the solution. Reaction 2 can be known as the rate controlling step because reaction 3 , a proton-transfer reaction, is about 1000 times faster than reaction 2 [14]. Therefore, the overall reaction can be represented by equation 4 .

$$
\mathrm{CO}_{2}+2 \mathrm{HO}^{-} \rightarrow \mathrm{CO}_{3}^{2-}+\mathrm{H}_{2} \mathrm{O}
$$

When the sodium hydroxide is in excess, the reaction between the dissolved carbon dioxide and the sodium hydroxide in solution is total end irreversible. According to

\footnotetext{
* email: sdragan@chem.ubbcluj.ro
} 
Danckwerts mass-transfer model [8] the reaction rate can be expressed as:

$$
v_{a x z}=a_{e} \cdot C_{\mathrm{CO}_{2}}^{i} \cdot \sqrt{k_{1}} \cdot D_{\mathrm{CO}_{2}}+k_{L}^{2}
$$

The mass-transfer process of the carbon dioxide absorption is controlled by the liquid film, according to Henry's law:

$$
C_{\mathrm{CO}_{2}}^{i}=H \cdot P_{\mathrm{CO}_{2}}
$$

In the fast reaction regime, defined by Hatta number, $\mathrm{Ha}>5$, the enhancement factor equals the Hatta number and the rapid chemical reaction is not influenced by the liquid side mass transfer coefficient $k_{\mathrm{L}}$ so that, the equation of the reaction rate becomes:

$$
v_{a b s}=a_{\varepsilon} \cdot H \cdot P_{c O_{2}} \cdot \sqrt{k_{1}} \cdot D_{c O_{2}}
$$

The solubility coefficient of carbon dioxide in the electrolyte solution can be estimated as follow:

$$
\begin{gathered}
\lg \frac{H}{H_{0}}=-K_{s} \cdot I \\
K_{s}=i_{+}+i_{-}+i_{g}=i_{\mathrm{Na}^{+}}+i_{\mathrm{HO}}+i_{\mathrm{CO}_{5}^{--}}+i_{\mathrm{CO}_{2}}
\end{gathered}
$$

For the system $\mathrm{CO}_{2}-\mathrm{NaOH}-\mathrm{H}_{2} \mathrm{O}$ ion coefficients are [8]:

$$
\begin{aligned}
& i_{\mathrm{Na}^{+}}=0.091 ; \\
& i_{\mathrm{HO}^{-}}=0.066 ; \\
& i_{\mathrm{CO}_{3}^{-}}=0.021 \\
& i_{\mathrm{CO}_{2}}=-0.019
\end{aligned}
$$

So, $K_{s}=0,159$ and equation (8) become:

$$
\lg \frac{H}{H_{0}}=-0.159 \cdot I
$$

The solubility coefficient of carbon dioxide in pure water, $\mathrm{H}_{0}$, depends only on temperature and can be calculated with relation [8]:

$$
\lg H_{0}=\frac{1140}{T}-5.30
$$

The rate constant of the pseudo-first-order reaction is $k_{1}$ and its relationship with temperature and ionic concentration is $[9,15]$ :

$$
k_{1}=k_{2} \cdot C_{H O}
$$

where $k_{2}$ is the pseudo-second-order rate constant.

$$
\begin{aligned}
& \lg \left(\frac{k_{2}}{k_{2}^{\infty}}\right)=0.1987 I-0.012 I^{2} \\
& \lg k_{2}^{\infty}=11.895-\frac{2382}{T}
\end{aligned}
$$

The formula for the ionic strength is as follows:

$$
I=\frac{1}{2} \sum C_{i} \cdot Z_{i}^{2}=C_{N a O H}^{0}
$$

Using the equation system (17):

$$
\begin{aligned}
& C_{\mathrm{CO}_{2}}^{i}=H \cdot P_{\mathrm{CO}_{2}} \\
& H=H_{0} \cdot 10^{-0.159 C_{\text {SOOS }}^{i}} \\
& \lg H_{0}=\frac{1140}{T}-5.30
\end{aligned}
$$

the concentration of carbon dioxide at interface $\mathrm{C}_{\mathrm{CO}_{2}}^{i}$ can be determined.
When the Hatta number is $\mathrm{Ha}>5$, the enhancement factor $\mathrm{E}=\mathrm{Ha}$ and the absorption rate equation becomes:

$$
v_{a b s}=a_{e} \cdot C_{C Q_{2}}^{i} \cdot \sqrt{k_{2} \cdot C_{H \sigma}^{0} \cdot D_{C O}}
$$

The condition $\mathrm{E}=\mathrm{Ha}$, when $\mathrm{Ha}>5$, is necessary but not sufficient, because at $\mathrm{Ha}>5$ the reaction may become spontaneous, therefore there is a global condition that must be fulfilled [8]:

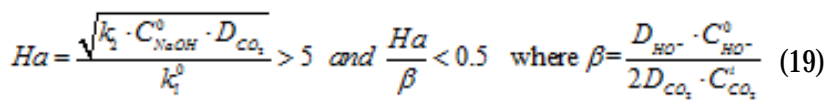

If were present the equation (18), $v_{a b s}=f\left(C_{\mathrm{CO}_{2}}^{i} \cdot \sqrt{k_{2} \cdot \mathrm{C}_{\mathrm{HO}}^{0} \cdot D_{\mathrm{CO}_{2}}}\right)$ the effective mass transfer area $\left(a_{e}\right)$ can be obtained as the slope of the straight line passing through the origin.

\section{Experimental part}

For determining the effective mass transfer area in three phase fluidized bed with low density inert packing, the rate of carbon dioxide absorption from air-carbon dioxide mixture in solutions of sodium hydroxide of two concentrations was measured.

The flow diagram of the experimental equipment used for the absorption rate and the effective mass transfer area measurements is represented in Figure 1.

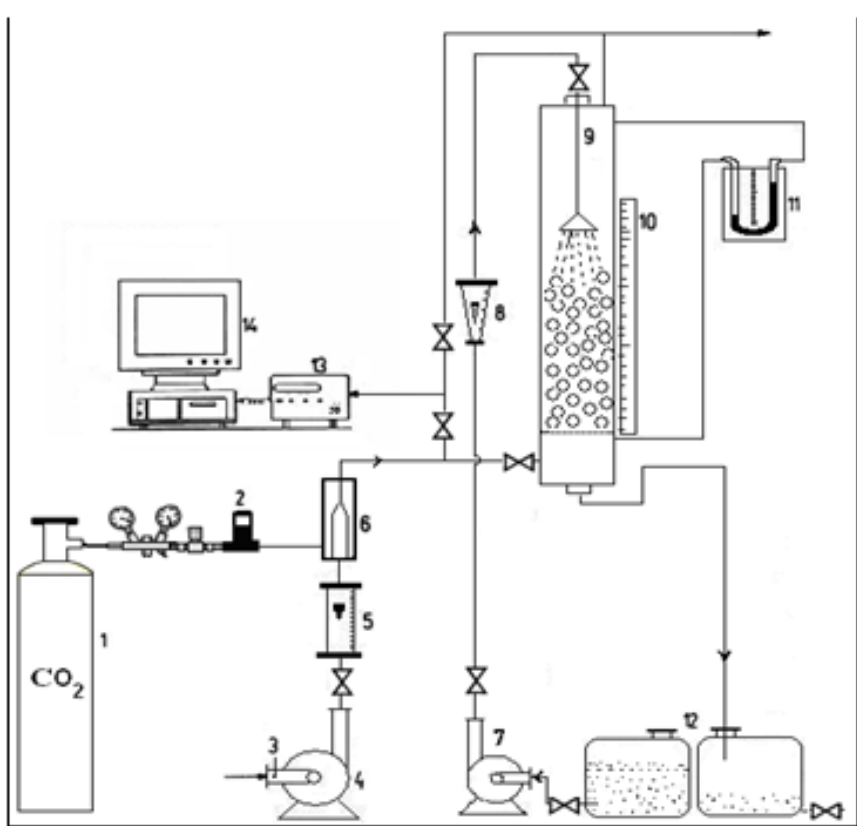

Fig. 1. Flow diagram of the experimental equipment

The absorption column was made of glass with an interior diameter of $0.14 \mathrm{~m}$ and a height of $1.10 \mathrm{~m}$. Gas mixture is the continuous phase and was introduced at the bottom of the column at predetermined flow rate into the column, to provide a greater velocity than the fluidization velocity. The sodium hydroxide solution of specified concentration as dispersed phase was sprayed with the liquid distributor in the fluidized bed column.

The solid materials which were used as solid phase are plastic hollow balls of $0.01 \mathrm{~m}$ diameter, with $415 \mathrm{~m}^{2} / \mathrm{m}^{3}$ geometric area and a density of $170 \mathrm{Kg} / \mathrm{m}^{3}$. The experiments were conducted in a fully fluidized state. The fluidized bed height was read on the scale. The liquid and air flow rates were measured by rotameters and the carbon dioxide flow rate was measured and controlled by the mass flow controller.

When the steady state conditions were established in the column, carbon dioxide at specified concentration was 


\begin{tabular}{|l|l|}
\hline \multicolumn{1}{|c|}{ Variable } & \multicolumn{1}{c|}{ Range } \\
\hline Column diameter $\mathrm{D}_{c}[\mathrm{~m}]$ & 0.14 \\
\hline Diameter of solid particle $\mathrm{d}_{\mathrm{p}}[\mathrm{m}]$ & 0.01 \\
\hline Solid particle density $\left[\mathrm{Kg} / \mathrm{m}^{3}\right]$ and geometric area $\left[\mathrm{m}^{2} / \mathrm{m}^{3}\right]$ & 170 \\
& 415 \\
\hline Gas velocity $\mathrm{v}_{\mathrm{g}}[\mathrm{m} / \mathrm{s}]$ & $1.1 ; 2.11$ \\
\hline $\mathrm{CO}_{2}$ mole fraction in the gas mixture & $0.05 ; 0.08 ; 0.1$ \\
\hline Liquid load $\left[\mathrm{m}^{3} / \mathrm{m}^{2} \mathrm{~h}\right]$ & $6.49 ; 9.74 ; 12.99 ; 16.24$ \\
\hline Concentration of $\mathrm{NaOH}$ solution, $[\mathrm{mol} / \mathrm{I}]$ & $0.5 ; 1.0$ \\
\hline
\end{tabular}

Table 1

THE EXPERIMENTAL CONDITIONS

( $T=293 \mathrm{~K}, \mathrm{P}=1$ bar) mixed with the air and introduced into the column. In order to determine the carbon dioxide absorption rate into sodium hydroxide solution in the fluidized bed, gas phase at specified time was passed through the gas analyzer to determine the carbon dioxide concentration. The composition of carbon dioxide at the inlet and outlet of the column was measured using a calibrate BINOS 120 gas analyzer.

The experimental conditions are presented in Table 1.

The gas mixtures containing $5 \%, 8 \%$ and $10 \%$ vol. $\mathrm{CO}_{2}$ have been prepared from air and carbon dioxide of $99.99 \%$ purity from Linde Gas Romania. The aqueous sodium hydroxide solutions with $0.5 \mathrm{~mol} / /$ and $1 \mathrm{~mol} / /$ concentration have been prepared from distilled water and sodium hydroxide of $99.99 \%$ purity from Merck $\mathrm{GmbH}$. The absorption rate has been calculated out of the fluidized bed height $\left(\mathrm{H}_{\mathrm{sf}}\right)$ measurement and the concentration of carbon dioxide in the gas phase at inlet $\left(\mathrm{Y}_{\mathrm{CO} 2}\right)$ and outlet $\left(\mathrm{Y}_{\mathrm{CO} 2}\right)$ from the column.

\section{Results and discussions}

For determining the rate of the mass transfer of carbon dioxide into sodium hydroxide solution of specified concentration in the three phase fluidized bed, the carbon dioxide concentration at the inlet and outlet of the system was used. With these values and the height of the fluidized bed, the absorption rate for the two concentrations of sodium hydroxide solutions and the two gas velocity were determined:

$$
v_{a b}=\frac{273}{293} \cdot \frac{w_{g}}{22.4} \cdot \frac{1}{H_{s f}}\left(Y_{\mathrm{CO}_{2}}^{i}-Y_{\mathrm{CO}_{2}}^{f}\right)
$$

The reaction constant $k_{2}$ was calculated using the following relations:

Barett equation [16]:

$$
\lg k_{2}=11.8609-\frac{2338.28}{T}+0.1317 \cdot C_{\mathrm{NaOH}}^{0}
$$

Astarita equation [17]:

$$
\lg k_{2}=13.635-\frac{2895}{T}+0.160 \cdot C_{\mathrm{NaOH}}^{0}
$$

Pohorecki equation [18]:

$$
\lg k_{2}=11.895-\frac{2382}{T}+0.221 \cdot C_{\mathrm{MaCH}}^{\circ}-0.016\left(C_{\mathrm{MoH}}^{0}\right)^{2}
$$

And these are presented in Table 2.

From Table 2 it can be observed that the values of $k_{2}$ obtained with the equation (23) are approximatively the mean values obtained with equations (21) and (22), therefore these values were used.

\section{Table 2}

VALUES OF THE REACTION CONSTANT $k_{2}[\mathrm{l} / \mathrm{mol} \mathrm{s}]$ AT T $=293 \mathrm{~K}$

\begin{tabular}{|l|c|c|c|}
\hline $\begin{array}{c}\text { Equation } \rightarrow \\
\mathrm{C}^{0} \mathrm{NaOH} \\
\downarrow\end{array}$ & $(21)$ & $(22)$ & $(23)$ \\
\hline 0 & 7593.154 & 5681.381 & 5825.151 \\
\hline $0.5 \mathrm{~N}$ & 8836.335 & 6830.522 & 7444.014 \\
\hline $1 \mathrm{~N}$ & 10283.06 & 8212.094 & 9339.146 \\
\hline
\end{tabular}

The carbon dioxide diffusivity in pure water depends on the temperature as follows [8]:

$$
\lg D_{\mathrm{CO}_{2}}^{0}=-8.1764+\frac{712.5}{T}-\frac{2.591 \cdot 10^{5}}{T^{2}}
$$

While the diffusivity of the carbon dioxide in the sodium hydroxide aqueous solution was calculated by the equation [18]:

$$
D_{\mathrm{CO}_{2}}=D_{\mathrm{CO}_{2}}^{0} \cdot\left(\frac{\eta_{\mathrm{H}_{2} \mathrm{O}}}{\eta_{\mathrm{NaOH}}}\right)^{0.637}
$$

Using equations $(24,25)$ and the viscosity values of sodium hydroxide aqueous solutions, the diffusion coefficient $D_{\mathrm{CO}_{2}}$ has been calculated. Henry constants of carbon dioxide in sodium hydroxide aqueous solutions have been determined and are presented in Table 3.

In the Tables 4 to 7 the concentrations of carbon dioxide at interfaces, the absorption rates and the $X$ coordinate from equation (18) are being presented.

The effective mass transfer area was determined as a slope of the straight line obtained from equation (18):

$$
v_{a b s}=f\left(X=C_{\mathrm{CO}_{2}}^{i} \cdot \sqrt{k_{2} \cdot \mathrm{C}_{\mathrm{HO}}^{\circ} \cdot D_{\mathrm{CO}_{2}}}\right) \text { and are plotted in }
$$

Figures 2-5.

The determined numerical values of the effective mass transfer area are centralized in Table 8.

The values from Table 8 show that the effective mass transfer area increased with an increase in both the gas velocity and the liquid spray density. At a constant concentration of the sodium hydroxide solution and a constant absorbent liquid loading the effective mass transfer area increases with gas velocity, from $1705 \mathrm{~m}^{2} / \mathrm{m}^{3}$ $\left(C_{\mathrm{NaOH}}=0.5 \mathrm{~mol} / \mathrm{l}, v_{\mathrm{o}}=1.1 \mathrm{~m} / \mathrm{s}\right.$ and $\left.q_{1}=16.24 \mathrm{~m}^{3} / \mathrm{m}^{2} \mathrm{~h}\right)$ to $3352 \mathrm{~m}^{2} / \mathrm{m}^{3}\left(C_{10 \mathrm{H}}=0.5 \mathrm{~mol} / \mathrm{l}, \mathrm{v}_{2}=2.11 \mathrm{~m} / \mathrm{s}\right.$ and $\mathrm{q}_{1}=16.24$ $\mathrm{m}^{3} / \mathrm{m}^{2} \mathrm{~h}$ ). The phenomenon can be explained due to the turbulence and the solid packing movements and due to higher gas velocity which determines the intensifying of the phase mixing and due to a better fluidization so that all these determine the increase of the effective mass transfer area.

At a constant concentration of the sodium hydroxide solution and a constant gas velocity the effective mass transfer area increases with the increase of the liquid spray density, from $1527 \mathrm{~m}^{2} / \mathrm{m}^{3}\left(\mathrm{C}_{\mathrm{NaH}}=0.5 \mathrm{~mol} / \mathrm{l}, \mathrm{v}=1.1 \mathrm{~m} / \mathrm{s}\right.$ and $\left.q_{1}=6.49 \mathrm{~m}^{3} / \mathrm{m}^{2} \mathrm{~h}\right)$ to $1705 \mathrm{~m}^{2} / \mathrm{m}^{3}\left(\mathrm{C}_{\mathrm{NaOH}}=0.5 \mathrm{~mol} / \mathrm{l}\right.$,

Table 3

DIFFUSION COEFFICIENTS $D_{\text {CO2 }}$ IN SODIUM HYDROXIDE SOLUTIONS AND HENRY CONSTANTS H AT T $=293 \mathrm{~K}$

\begin{tabular}{|l|c|c|c|}
\hline $\mathrm{C}^{\mathrm{W}} \mathrm{NaH}$ & 0 & 0.5 & 1 \\
\hline$\left(\frac{\eta_{\mathrm{H}_{2} \mathrm{O}}}{\eta_{\mathrm{NaOH}}}\right)$ & 1 & 0.8879 & 0.7762 \\
\hline$D_{\mathrm{Ca}_{2}} \cdot 10^{9}\left[\mathrm{~m}^{2} / \mathrm{s}\right]$ & 1.76 & 1.65 & 1.54 \\
\hline$H \cdot 10^{2}[\mathrm{~atm} \cdot 1 / \mathrm{mol}]$ & 3.897 & 3.245 & 2.7 \\
\hline
\end{tabular}




\begin{tabular}{|c|c|c|c|c|}
\hline $\mathrm{C}_{\mathrm{CO} 2}$ & $\mathrm{C}^{\mathrm{i}} \mathrm{CO2}$ & $C_{\mathrm{CO}}^{i} \sqrt{k_{2} \cdot C_{\mathrm{HO}^{-}}^{0} \cdot D_{\mathrm{CO}}}$ & $\begin{array}{c}v_{\Delta b} \mathrm{x} l 0^{3} \\
{\left[\mathrm{Kmol} / \mathrm{m}^{3} \mathrm{~s}\right]}\end{array}$ & $\begin{array}{l}\text { Liquid load } \\
{\left[\mathrm{m}^{3} / \mathrm{m}^{2} \mathrm{~h}\right]}\end{array}$ \\
\hline 0 & 0 & 0 & 0 & \multirow{4}{*}{$q_{1}=6.49$} \\
\hline $5 \%$ & $1.6200 \mathrm{E}-03$ & $4.1940 \mathrm{E}-06$ & 6.221753 & \\
\hline $8 \%$ & $2.6000 \mathrm{E}-03$ & $6.7300 \mathrm{E}-06$ & 10.433075 & \\
\hline $10 \%$ & $3.2400 \mathrm{E}-03$ & $8.3900 \mathrm{E}-06$ & 12.784895 & \\
\hline 0 & 0 & 0 & 0 & \multirow{4}{*}{$q_{1}=9.74$} \\
\hline $5 \%$ & $1.6200 \mathrm{E}-03$ & $4.1940 \mathrm{E}-06$ & 6.554111 & \\
\hline $8 \%$ & $2.6000 \mathrm{E}-03$ & $6.7300 \mathrm{E}-06$ & 10.758887 & \\
\hline $10 \%$ & $3.2400 \mathrm{E}-03$ & $8.3900 \mathrm{E}-06$ & 13.108221 & \\
\hline 0 & 0 & 0 & 0 & \multirow{4}{*}{$q_{1}=12.99$} \\
\hline $5 \%$ & $1.6200 \mathrm{E}-03$ & $4.1940 \mathrm{E}-06$ & 6.815129 & \\
\hline $8 \%$ & $2.6000 \mathrm{E}-03$ & $6.7300 \mathrm{E}-06$ & 11.182052 & \\
\hline $10 \%$ & $3.2400 \mathrm{E}-03$ & $8.3900 \mathrm{E}-06$ & 13.601283 & \\
\hline 0 & 0 & 0 & 0 & \multirow{4}{*}{$\mathrm{q}_{1}=16.24$} \\
\hline $5 \%$ & $1.6200 \mathrm{E}-03$ & $4.1940 \mathrm{E}-06$ & 6.977425 & \\
\hline $8 \%$ & $2.6000 \mathrm{E}-03$ & $6.7300 \mathrm{E}-06$ & 11.440639 & \\
\hline $10 \%$ & $3.2400 \mathrm{E}-03$ & $8.3900 \mathrm{E}-06$ & 14.419043 & \\
\hline
\end{tabular}

\begin{tabular}{|c|c|c|c|c|}
\hline $\mathrm{C}_{\mathrm{CO} 2}$ & $\mathrm{C}^{\mathrm{i}} \mathrm{CO2}$ & $C_{\mathrm{CO},}^{i} \sqrt{k_{2} \cdot C_{\mathrm{HO}^{-}}^{0} \cdot D_{\mathrm{CO}}}$ & $\begin{array}{c}v_{\Delta \mathrm{b}} \mathrm{x} 10^{3} \\
{\left[\mathrm{Kmol} / \mathrm{m}^{3} \mathrm{~s}\right]}\end{array}$ & $\begin{array}{l}\text { Liquid load } \\
{\left[\mathrm{m}^{3} / \mathrm{m}^{2} \mathrm{~h}\right]}\end{array}$ \\
\hline 0 & 0 & 0 & 0 & \multirow{4}{*}{$\mathrm{q}=6.49$} \\
\hline $5 \%$ & $1.3500 \mathrm{E}-03$ & $5.2300 \mathrm{E}-06$ & 6.636536 & \\
\hline $8 \%$ & $2.1600 \mathrm{E}-03$ & $8.3700 \mathrm{E}-06$ & 11.128613 & \\
\hline $10 \%$ & $2.7000 \mathrm{E}-03$ & $1.0500 \mathrm{E}-05$ & 13.637221 & \\
\hline 0 & 0 & 0 & 0 & \multirow{4}{*}{$\mathrm{q}=9.74$} \\
\hline $5 \%$ & $1.3500 \mathrm{E}-03$ & $5.2300 \mathrm{E}-06$ & 6.991051 & \\
\hline $8 \%$ & $2.1600 \mathrm{E}-03$ & $8.3700 \mathrm{E}-06$ & 11.476146 & \\
\hline $10 \%$ & $2.7000 \mathrm{E}-03$ & $1.0500 \mathrm{E}-05$ & 14.855984 & \\
\hline 0 & 0 & 0 & 0 & \multirow{4}{*}{$\mathrm{q}=12.99$} \\
\hline $5 \%$ & $1.3500 \mathrm{E}-03$ & $5.2300 \mathrm{E}-06$ & 7.520142 & \\
\hline $8 \%$ & $2.1600 \mathrm{E}-03$ & $8.3700 \mathrm{E}-06$ & 12.338816 & \\
\hline $10 \%$ & $2.7000 \mathrm{E}-03$ & $1.0500 \mathrm{E}-05$ & 14.539302 & \\
\hline 0 & 0 & 0 & 0 & \multirow{4}{*}{$q_{1}=16.24$} \\
\hline $5 \%$ & $1.3500 \mathrm{E}-03$ & $5.2300 \mathrm{E}-06$ & 7.92032 & \\
\hline $8 \%$ & $2.1600 \mathrm{E}-03$ & $8.3700 \mathrm{E}-06$ & 12.986671 & \\
\hline $10 \%$ & $2.7000 \mathrm{E}-03$ & $1.0500 \mathrm{E}-05$ & 15.17794 & \\
\hline
\end{tabular}

\begin{tabular}{|c|c|c|c|c|}
\hline $\mathrm{C}_{\mathrm{CO} 2}$ & $\mathrm{C}^{\mathrm{i}} \mathrm{CO2}$ & $C_{\mathrm{CO}}^{i} \sqrt{k_{2} \cdot C_{\mathrm{HO}^{-}}^{0} \cdot D_{\mathrm{CO}}}$ & $\begin{array}{c}v_{\mathrm{atb}} \times 10^{3} \\
{\left[\mathrm{Kmol} / \mathrm{m}^{3} \mathrm{~s}\right]}\end{array}$ & $\begin{array}{l}\text { Liquid loac } \\
{\left[\mathrm{m}^{3} / \mathrm{m}^{2} \mathrm{~h}\right]}\end{array}$ \\
\hline 0 & 0 & 0 & 0 & \multirow{4}{*}{$\mathrm{q}_{1}=6.49$} \\
\hline $5 \%$ & $1.6200 \mathrm{E}-03$ & $4.1940 \mathrm{E}-06$ & 11.137704 & \\
\hline $8 \%$ & $2.6000 \mathrm{E}-03$ & $6.7300 \mathrm{E}-06$ & 17.339647 & \\
\hline $10 \%$ & $3.2400 \mathrm{E}-03$ & $8.3900 \mathrm{E}-06$ & 19.845364 & \\
\hline 0 & 0 & 0 & 0 & \multirow{4}{*}{$\mathrm{q}_{1}=9.74$} \\
\hline $5 \%$ & $1.6200 \mathrm{E}-03$ & $4.1940 \mathrm{E}-06$ & 11.321419 & \\
\hline $8 \%$ & $2.6000 \mathrm{E}-03$ & $6.7300 \mathrm{E}-06$ & 18.515994 & \\
\hline $10 \%$ & $3.2400 \mathrm{E}-03$ & $8.3900 \mathrm{E}-06$ & 21.847037 & \\
\hline 0 & 0 & 0 & 0 & \multirow{4}{*}{$\mathrm{q}_{1}=12.99$} \\
\hline $5 \%$ & $1.6200 \mathrm{E}-03$ & $4.1940 \mathrm{E}-06$ & 13.427058 & \\
\hline $8 \%$ & $2.6000 \mathrm{E}-03$ & $6.7300 \mathrm{E}-06$ & 19.669209 & \\
\hline $10 \%$ & $3.2400 \mathrm{E}-03$ & $8.3900 \mathrm{E}-06$ & 24.171189 & \\
\hline 0 & 0 & 0 & 0 & \multirow{4}{*}{$\mathrm{q}_{1}=16.24$} \\
\hline $5 \%$ & $1.6200 \mathrm{E}-03$ & $4.1940 \mathrm{E}-06$ & 15.131758 & \\
\hline $8 \%$ & $2.6000 \mathrm{E}-03$ & $6.7300 \mathrm{E}-06$ & 22.53118 & \\
\hline $10 \%$ & $3.2400 \mathrm{E}-03$ & $8.3900 \mathrm{E}-06$ & 0.027620566 & \\
\hline
\end{tabular}

Table 5

EXPERIMENTAL RESULTS FOR THE ABSORPTION OF $\mathrm{CO}_{2}$ INTO IN NaOH AQUEOUS SOLUTION IN THREE PHASE FLUIDIZED BED AT $v_{\mathrm{g}}=1.1 \mathrm{~m} / \mathrm{s}$

EXPERIMENTAL RESULTS FOR THE ABSORPTION OF CO, INTO $0.5 \mathrm{~N} \mathrm{NaOH}$ AQUEOUS SOLUTION IN THREE PHASE FLUIDIZED BED AT $v_{g}=1.1 \mathrm{~m} / \mathrm{s}$ 


\begin{tabular}{|c|c|c|c|c|}
\hline $\mathrm{C}_{\mathrm{CO} 2}$ & $\mathrm{C}^{\mathrm{i}} \mathrm{CO2}$ & $C_{\mathrm{CO}}^{i} \sqrt{k_{2} \cdot C_{\mathrm{HO}}^{0} \cdot D_{\mathrm{CO}}}$ & $\begin{array}{c}v_{\Delta b} \times 10^{3} \\
{\left[\mathrm{Kmol} / \mathrm{m}^{3} \mathrm{~s}\right]}\end{array}$ & $\begin{array}{l}\text { Liquid load } \\
{\left[\mathrm{m}^{3} / \mathrm{m}^{2} \mathrm{~h}\right]}\end{array}$ \\
\hline 0 & 0 & 0 & 0 & \multirow{4}{*}{$\mathrm{q}_{1}=6.49$} \\
\hline $5 \%$ & $1.3500 \mathrm{E}-03$ & $5.2300 \mathrm{E}-06$ & 12.622731 & \\
\hline $8 \%$ & $2.1600 \mathrm{E}-03$ & $8.3700 \mathrm{E}-06$ & 20.329241 & \\
\hline $10 \%$ & $2.7000 \mathrm{E}-03$ & $1.0500 \mathrm{E}-05$ & 24.097942 & \\
\hline 0 & 0 & 0 & 0 & \multirow{4}{*}{$\mathrm{q}_{\mathrm{l}}=9.74$} \\
\hline $5 \%$ & $1.3500 \mathrm{E}-03$ & $5.2300 \mathrm{E}-06$ & 13.273388 & \\
\hline $8 \%$ & $2.1600 \mathrm{E}-03$ & $8.3700 \mathrm{E}-06$ & 20.984793 & \\
\hline $10 \%$ & $2.7000 \mathrm{E}-03$ & $1.0500 \mathrm{E}-05$ & 26.216444 & \\
\hline 0 & 0 & 0 & 0 & \multirow{4}{*}{$\mathrm{q} l=12.99$} \\
\hline $5 \%$ & $1.3500 \mathrm{E}-03$ & $5.2300 \mathrm{E}-06$ & 15.217332 & \\
\hline $8 \%$ & $2.1600 \mathrm{E}-03$ & $8.3700 \mathrm{E}-06$ & 22.947411 & \\
\hline $10 \%$ & $2.7000 \mathrm{E}-03$ & $1.0500 \mathrm{E}-05$ & 29.005427 & \\
\hline 0 & 0 & 0 & 0 & \multirow{4}{*}{$\mathrm{q} 1=16.24$} \\
\hline $5 \%$ & $1.3500 \mathrm{E}-03$ & $5.2300 \mathrm{E}-06$ & 17.401522 & \\
\hline $8 \%$ & $2.1600 \mathrm{E}-03$ & $8.3700 \mathrm{E}-06$ & 27.037416 & \\
\hline $10 \%$ & $2.7000 \mathrm{E}-03$ & $1.0500 \mathrm{E}-05$ & 34.525708 & \\
\hline
\end{tabular}

Table 7

EXPERIMENTAL RESULTS FOR THE ABSORPTION OF $\mathrm{CO}_{2}$ INTO IN NaOH AQUEOUS SOLUTION IN THREE PHASE FLUIDIZED BED AT $\mathrm{V}_{\mathrm{g}}=2.1 \mathrm{~m} / \mathrm{s}$

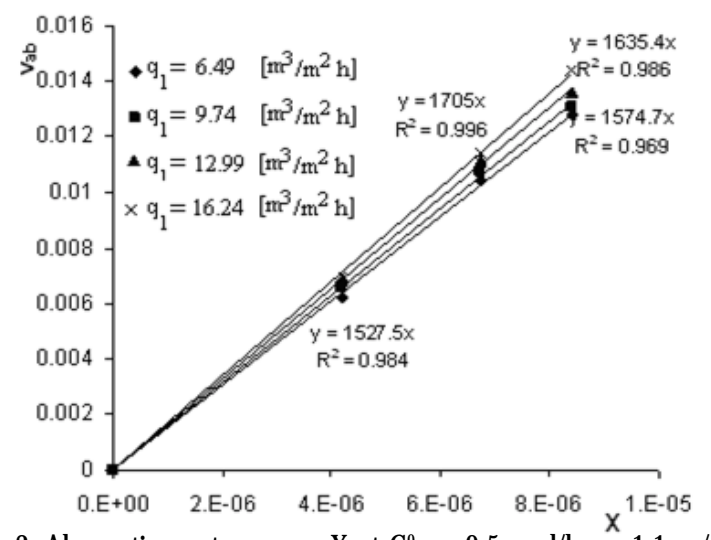

Fig. 2. Absorption rate versus $X$ at $\mathrm{C}_{\mathrm{HO}}{ }^{0}=0.5 \mathrm{~mol} / \mathrm{l}, \mathrm{v}_{\mathrm{g}}^{X}=1.1 \mathrm{~m} / \mathrm{s}$, $\mathrm{T}=293 \mathrm{~K}$

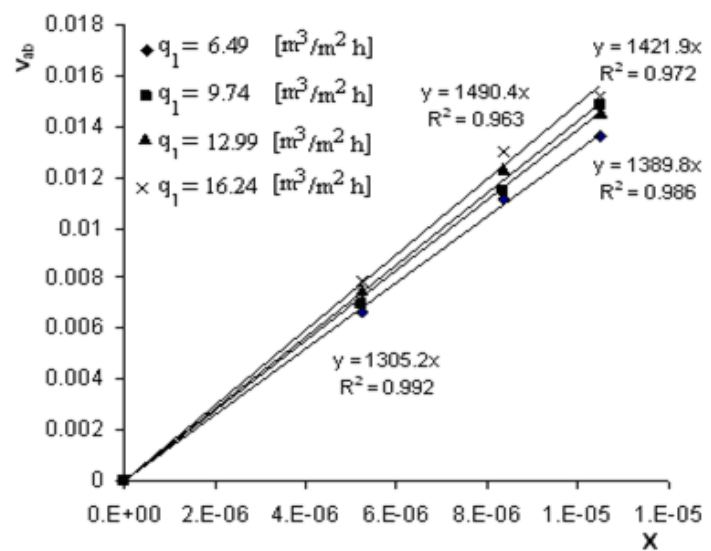

Fig. 3. Absorption rate versus $X$ at $\mathrm{C}_{\mathrm{HO}}{ }_{\mathrm{HO}}=1 \mathrm{~mol} / \mathrm{l}, \mathrm{v}_{\mathrm{g}}=1.1 \mathrm{~m} / \mathrm{s}$, $\mathrm{T}=293 \mathrm{~K}$

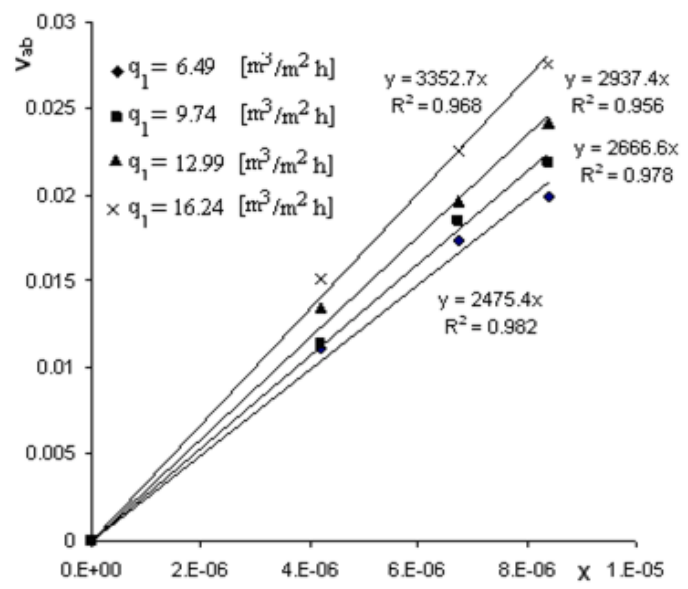

Fig. 4. Absorption rate versus $X$ at $\mathrm{C}_{\text {но }}^{0}=0.5 \mathrm{~mol} / \mathrm{l}, \mathrm{v}_{\mathrm{g}}=2.11 \mathrm{~m} / \mathrm{s}$, $\mathrm{T}=293 \mathrm{~K}$

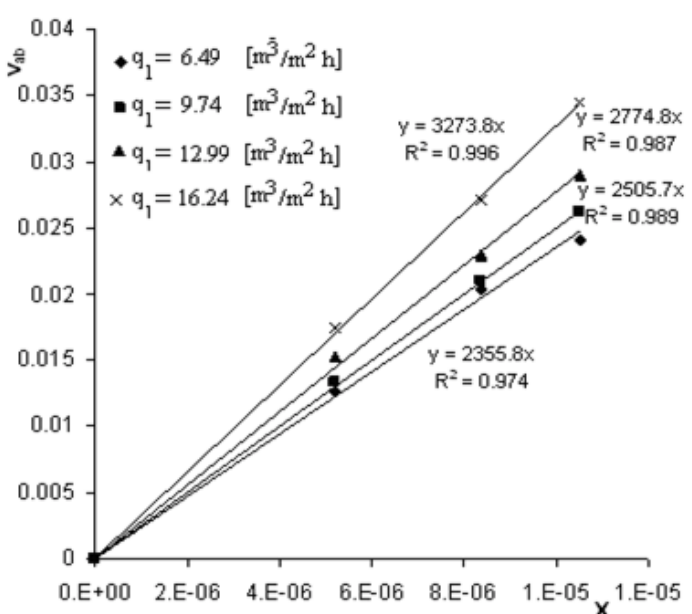

Fig. 5. Absorption rate versus $X$ at $C_{{ }_{H O}}=1 \mathrm{~mol} / \mathrm{l}, \mathrm{V}_{\mathrm{g}}^{X}=2.11 \mathrm{~m} / \mathrm{s}$, $\mathrm{T}=293 \mathrm{~K}$

\section{Table 8}

EFFECTIVE MASS TRANSFER AREA IN GAS-SOLID-LIQUID THREE PHASE FLUIDIZED BED WITH LOW DENSITY INERT SOLID PARTICLES $\left(a_{e^{\prime}} \mathrm{m}^{2} / \mathrm{m}^{3}\right)$

\begin{tabular}{|c|c|c|c|c|c|}
\hline $\mathrm{C}^{\mathrm{H}} \mathrm{Ho}^{-/} \mathrm{qL}\left[\mathrm{m}^{3} / \mathrm{m}^{2} \mathrm{~h}\right]$ & 6.49 & 9.74 & 12.99 & 16.24 & $v_{g}[\mathrm{~m} / \mathrm{s}]$ \\
\hline $0.5 \mathrm{~mol} / 1$ & 1527.5 & 1574.7 & 1635.4 & 1705 & \multirow{3}{*}{1.1} \\
\hline $1 \mathrm{~mol} / \mathrm{l}$ & 1305.2 & 1389.8 & 1421.9 & 1490.4 & \\
\hline Average & 1416.3 & 1482.2 & 1528.6 & 1597.7 & \\
\hline $0.5 \mathrm{~mol} / \mathrm{l}$ & 2475.4 & 2666.6 & 2937.4 & 3352.7 & \multirow{3}{*}{2.11} \\
\hline $1 \mathrm{moll}$ & 2355.8 & 2505.7 & 2774.8 & 3273.8 & \\
\hline Average & 2415.6 & 2586.15 & 2856.1 & 3313.25 & \\
\hline
\end{tabular}




\begin{tabular}{|c|c|c|c|c|c|c|}
\hline $\mathrm{q}\left[\left[\mathrm{m}^{3} / \mathrm{m}^{2} \mathrm{~h}\right]\right.$ & 6.49 & 9.74 & 12.99 & 16.24 & $\mathrm{v}_{\mathrm{g}}[\mathrm{m} / \mathrm{s}]$ & \multirow{7}{*}{$\begin{array}{c}\text { Table } 9 \\
\text { VALIDATION OF THE RELATIONS (26) }\end{array}$} \\
\hline$a_{c \text { (experimental) }}$ & 1416.3 & 1482.2 & 1528.6 & 1597.7 & \multirow{3}{*}{1.1} & \\
\hline$a_{s}$ (este. se.26) & 1413.0 & 1487.2 & 1542.1 & 1586.1 & & \\
\hline Deviation \& (\%) & 0.23 & -0.33 & -0.88 & 0.72 & & \\
\hline$a_{c \text { (experimental) }}$ & 2415.6 & 2586.15 & 2856.1 & 3313.25 & \multirow{3}{*}{2.11} & \\
\hline$a_{s}$ (estits ds.26) & 2355.1 & 2694.9 & 2965.3 & 3193.5 & & \\
\hline Deviation \& (\%) & 2.5 & -4.21 & -3.82 & 3.61 & & \\
\hline
\end{tabular}

$v=1.1 \mathrm{~m} / \mathrm{s}$ and $q=16.24 \mathrm{~m}^{3} / \mathrm{m}^{2} \mathrm{~h}$ ). An increase in liquid loading, increases packing buoyancy and a better fluidization is obtained.

At a constant absorbent liquid loading and constant gas velocity, the effective mass transfer area decreases with the increase of the concentration of sodium hydroxide solution, from $1705 \mathrm{~m}^{2} / \mathrm{m}^{3}\left(\mathrm{C}_{\mathrm{a}-\mathrm{H}}=0.5 \mathrm{~mol} / \mathrm{l}, \mathrm{vg}=1.1 \mathrm{~m} / \mathrm{s}\right.$ and $\left.q_{1}=16.24 \mathrm{~m}^{3} / \mathrm{m}^{2} \mathrm{~h}\right)$ to $1490 \mathrm{~m}^{2} / \mathrm{m}^{3}\left(\mathrm{C}_{\mathrm{NaOH}}=1 \mathrm{~mol} / \mathrm{l}\right.$, $v_{c}=1.1 \mathrm{~m} / \mathrm{s}$ and $q_{1}=16.24 \mathrm{~m}^{3} / \mathrm{m}^{2} \mathrm{~h}$ ). This phenomenon can be explained using the two-films theory. The reaction of the carbon dioxide with sodium hydroxide takes place in liquid boundary layer, so carbon dioxide has to diffuse through the gas film and enter in the liquid film to reach the sodium hydroxide solution. Increasing the concentration of the sodium hydroxide solution causes an increased viscosity of the liquid, thus carbon dioxide diffusion in the liquid phase is slowed and the mass transfer area is decreased.

The values of the effective mass transfer area shown in Table 8, were correlated with the liquid loading obtaining relationships of the type:

$$
\begin{aligned}
& \frac{a_{\varepsilon}}{a_{g}}=2.69 \cdot q_{l}^{0.126} \text { at } \mathrm{v}_{g}=1.1 \mathrm{~m} / \mathrm{s} \\
& \frac{a_{g}}{a_{g}}=3.05 \cdot q_{l}^{0.311} \text { at } \mathrm{v}_{g}=2.11 \mathrm{~m} / \mathrm{s}
\end{aligned}
$$

The constants in the equations were established by regression. The relationships (26) express dimensionless equations which are valid only for the specified conditions. Effective mass transfer areas predicted by these equations and the deviation from the values determined from the experimental data are shown in Table 9.

From the Table 9 we can see that the equations (26) predicted the effective mass transfer area $\left(a_{e}\right)$ in a good agreement with those values determined from experimental data with a deviation $(\varepsilon)$ less of $5 \%$.

Validation of the condition (19). Under the carried out experimental conditions the values of $\mathrm{Ha}, \beta$ and $\mathrm{Ha} / \beta$ obtained with $k_{i}^{0}=2 \cdot 10^{-4} \mathrm{~m} / \mathrm{s}$ are presented in the Table 10.

Table 10

\begin{tabular}{|c|c|c|c|}
\hline$C_{\mathrm{NaOH}}^{0}$ & $\mathrm{ol} / \mathrm{l}]$ & 0.5 & 1 \\
\hline Ha & & 12.39 & 18.96 \\
\hline & $p_{\mathrm{CO}_{2}} \downarrow$ & & \\
\hline$\beta$ & 0.05 & 293.209 & 703.703 \\
\hline & 0.08 & 182.692 & 439.815 \\
\hline & 0.1 & 146.605 & 351.852 \\
\hline & 0.05 & 0.0422 & 0.0269 \\
\hline $\mathrm{Ha} / \beta$ & 0.08 & 0.0678 & 0.0431 \\
\hline & 0.1 & 0.0845 & 0.0538 \\
\hline
\end{tabular}

VALIDATION OF THE CONDITIONS: Ha $>5$ AND Ha/ $\beta<0.5$

The data in Table 10 shows that the condition imposed by relationship (19) was fulfilled for the work experimental conditions.

\section{Conclusions}

The effective mass transfer area in three phase fluidized bed with low density solid particles has been determined. The absorption of carbon dioxide from a mixture of air- $\mathrm{CO}_{2}$ into $0.5 \mathrm{~N}$ and $1 \mathrm{~N}$ aqueous sodium hydroxide solutions was employed as the model reaction of known kinetics.

The effective mass transfer area increases when gas velocity and the absorbent liquid loading increases and decreases with the increase of the concentration of the sodium hydroxide solution. The increase of the gas velocity causes more turbulences, therefore a better phase mixing and a bigger mass transfer area.

Increasing the liquid flow results into better fluidization and phase mixing which causes more surface renewal and fresher aqueous solution is minded for carbon dioxide diffuse in.

Increasing concentration of the sodium hydroxide solution causes increased viscosity of the liquid, thus carbon dioxide diffusion in liquid phase is slowed and mass transfer area is decreased.

The effective mass transfer area in three phase fluidized bed is from three to eight times higher than the geometric area of the packing. The values of the effective mass transfer area were correlated with the liquid loading in a relationship of dependence.

The experimental work conditions were validated.

\section{References}

1.BILLET, R., Packed Towers in Processing and Environmental Technology, 1.ed. Weinheim-New York-Basel-Cambridge- Tokyo, 1995, p.369-372.

2.REJL, F.J ., VALENZ, L., HAIDL, J., KORDAC, M., MOUCHA, T., On the modeling of gas-phase mass-transfer in metal sheet structured packings, Chem. Eng. Res. Des., 93, 2015, p.194-202.

3.SALEH, A.R., HOSSEINI, S.H., SHOJ AEE, S., AHMADI, G., CFD studies of pressure drop and increasing capacity in Mellapak Plus 750.Y structured packing. Chem. Eng. Technol.34, nr. 9, 2011, p.1402-1412. 4.HAQ, A., INAYAT, M.H., ZAMAN, M., CHUGHTAI, I.R., Liquid holdup in a pilot scale turbulent contact absorber - an experimental and comparative study, Chem. Eng. Technol., 33, nr. 12, 2010, p. 20592065.

5.BRUCE, A.E.R., SAI, P.S.T., KRISHNAIAH, K., Liquid holdup in turbulent bed contactor, Chem. Eng. J., 99, 2004, p. 203-212.

6.JINESCU, Gh., VASILESCU, P., ENACEANU, N.E., Viteza minimã de fluidizare în stratul fluidizat trifazic, Rev. Chim. (Bucharest), 50, no. 4, 1999, p. 259-269.

7.DRAGAN, S., GHIRISAN MICLAUS, A., Hydrodynamic Parameters of Gas-Solid-Liquid Three Phase Fluidized Bed with Low Density Solids, Rev. Chim. (Bucharest), 67, no.5, 2016, p. 887-891.

8.DANCKWERTS, P.V., Gas Liquid Reactions. McGraw-Hill Book Company, New York, 1970, p.

9.SHARMA, M.M., DANKWERTS, P.V., Chemical methods of measuring interfacial area and mass transfer coefficients in two fluids systems. Br. Chem. Eng. 15, nr. 4, 1970, p.522-527.

10.H. de BRITO, M., von STOCKAR, M., BANGERTER, A., BOMIO, P., LASO, M., Effective mass-transfer area in a pilot plant column equipped with structured packings and with ceramic rings. Ind. Eng. Chem. Res. 33, 1994, p. 647-656.

11.TSAI, R., SCHULTHEISS, P., KETTNER, A., LEWIS, C., SEIBERT, F., ELDRIDGE, B., ROCHELLE, G., Influence of surface tension on 
effective packing area, Ind. Eng. Chem. Res., 47 nr. 4, 2008, p.12531260.

12.TSAI, R., Mass Transfer Area of Structured Packing, PhD Dissertation, 2010, Austin, University of Texas.

13.LIU, G., YU, K., YUAN, X., LIU, C., New model for turbulent mass transfer and its application to the simulations of a pilot-scale randomly packed column for $\mathrm{CO}-\mathrm{NaOH}$ chemical absorption, Ind. Eng. Chem. Res. 45, 2006a, p. 3220-3229.

14.ONDA, K., TAKEUKI, H., OKUMOTO, Y., Mass transfer coefficients between gas and liquid in packed columns. J ournal of Chem. Eng. of Japan 1 nr. 1, 1968, p.56-62.
15.DRAGAN, S., Calculation of the effective mass transfer area in turbulent contact absorber, Stud. Univ. Chemia, 61, 2016, p.227-238. 16.BARETT, P.V.L., Gas absorption on a sieve plate, PhD Thesis, 1966, Cambridge University.

17.ASTARITA, G., SAVAGE D.V., BISIO, A., Gas treating with chemical solvents, John Wiley \& Sons, 1983, p. 210.

18.POHORECKI, R., MONIUK, W., Kinetics of reaction between carbon dioxide and hydroxyl ions in aqueous electrolyte solutions. Chem. Eng. Sci. 43 nr. 7, 1988, p.1677-1684.

Manuscript received: 17.08 .2019 